Abstracta Iranica Abstracta Iranica

Revue bibliographique pour le domaine irano-aryen

Volume 22 | 2001

Comptes rendus des publications de 1999

\title{
« La tragédie de Satan dans la mystique musulmane ». Le Diable 20 Colloque de Cerisy, Dervy, Cahiers de l'Hermétisme, 1998, pp. 101-106.
}

\section{Denise Aigle}

\section{OpenEdition}

12 Journals

\section{Édition électronique}

URL : http://journals.openedition.org/abstractairanica/36842

DOI : 10.4000/abstractairanica.36842

ISSN : 1961-960X

Éditeur :

CNRS (UMR 7528 Mondes iraniens et indiens), Éditions de l'IFRI

\section{Édition imprimée}

Date de publication : 15 mai 2001

ISSN : 0240-8910

Référence électronique

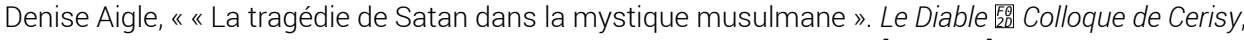
Dervy, Cahiers de l'Hermétisme, 1998, pp. 101-106. », Abstracta Iranica [En ligne], Volume 22 | 2001, document 377, mis en ligne le 17 février 2010, consulté le 09 octobre 2020. URL : http:// journals.openedition.org/abstractairanica/36842; DOI : https://doi.org/10.4000/abstractairanica. 36842

Ce document a été généré automatiquement le 9 octobre 2020.

Tous droits réservés 
« La tragédie de Satan dans la mystique musulmane ». Le Diable 20. Colloque de Cerisy, Dervy, Cahiers de l'Hermétisme, 1998, pp. 101-106.

\section{Denise Aigle}

1 Il existe dans le soufisme plusieurs figures qui ont appelé à valoriser le rôle d'iblīs, refusant de se prosterner devant Adam par fidélité à Dieu 医 seul digne d'adoration. Cet article expose la vision positive et paradoxale de Satan chez deux des plus illustres: Ḥallāj d'une part, 'Ayn al-Quḍāt Hamadānī de l'autre.

\section{INDEX}

Thèmes : 8. Soufisme

\section{AUTEURS}

DENISE AIGLE

EPHE - Paris 